\title{
The Flip Side of Economic Growth - Predictions from Indonesia
}

\author{
Irwansyah ${ }^{1}$, Ardi Paminto ${ }^{2}$, Zainal Ilmi ${ }^{3}$, Dio Caisar Darma ${ }^{*}$, Yana Ulfah ${ }^{5}$ \\ 1,2,3,5 Faculty of Economics and Business, Mulawarman University, Indonesia \\ ${ }^{4}$ Sekolah Tinggi Ilmu Ekonomi Samarinda, Indonesia \\ E-mail: 1irwansyah@feb.unmul.ac.id, ${ }^{2}$ ardi.paminto@feb.unmul.ac.id, ${ }^{3}$ zainal.ilmi@feb.unmul.ac.id, \\ ${ }^{4}$ diocaisar@stiesam.ac.id, ${ }^{5}$ yana.ulfah@feb.unmul.ac.id
}

"Corresponding author

JEL Classification:

A10

$\mathrm{J} 21$

$\mathrm{J} 24$

$\mathrm{C} 22$

Received: O1 April 2021

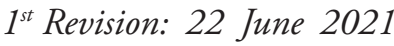

$2^{\text {nd }}$ Revision: 28 June 2021

Accepted: 12 July 2021

\begin{abstract}
Special attention in the future will emphasize patterns or studies that are relevant and new in highlighting sustainable economic growth. We seek to identify the role of factors outside of fiscal and monetary policy on economic growth in Indonesia, such as happiness, demographic pressures, labor force, and human development. For this purpose, the OLS method has presented time-series data (2015-2019). Prediction studies show that happiness, demographic pressures, and human development can increase economic growth in a significant direction. Another finding is that the labor force cannot significantly control economic growth, slowly decreasing growth with a negative slope. Practical contributions to developing countries can account for endogenous (internal) growth over the long term. The quality of human resources must prioritize productivity, income, and real welfare. The government needs to plan a policy framework oriented to the fiscal and monetary side.
\end{abstract}

\section{Keywords:}

Economic growth, labor, population, human resources, time-series, Indonesia

\section{How to Cite:}

Irwansyah, I., Paminto, A., IImi, Z., Darma, D. C., \& Ulfah, Y. (2022). The Flip Side of Economic Growth Predictions from Indonesia. Signifikan: Jurnal IImu Ekonomi, 11(1), 107-124. https://doi.org/10.15408/sjie. v11i1.20280. 


\section{INTRODUCTION}

Since the $20^{\text {th }}$ century, there has been new empirical evidence with a comprehensive presentation of social science through the literature to provide new theoretical insights into the relationship between productivity, socio-economic development, and gender equality. In particular, the initiation and long-term pace of intensive socio-economic development and a significant determinant of productivity variation in developed countries with the slogan "gender equality" (Anderson \& Kohler, 2015).

Some relevant literature has discussed the relationship between education and social realities, such as democracy, economic development, human development, happiness, and interaction (Zainurossalamia et al., 2021). However, only a few have investigated these social realities on the success of economic development. Empirically, the relationship between social reality and economic success is two-way. Many possibilities influence this democracy, health, education, and social happiness (Demirbolat, 2018).

In addition, there is much controversy over whether demand factors can affect the economic growth rate in the short run since wage contracts and asymmetric information can extend adjustments to long-run equilibrium. Apart from unanimity among economists on the role of the supply side, such as physical, human, and technological capital, to foster human development, to create economic growth and sustainable employment (Daud, 2017).

Figure 1. The rate of change of real GDP in Indonesia, 1991-2019

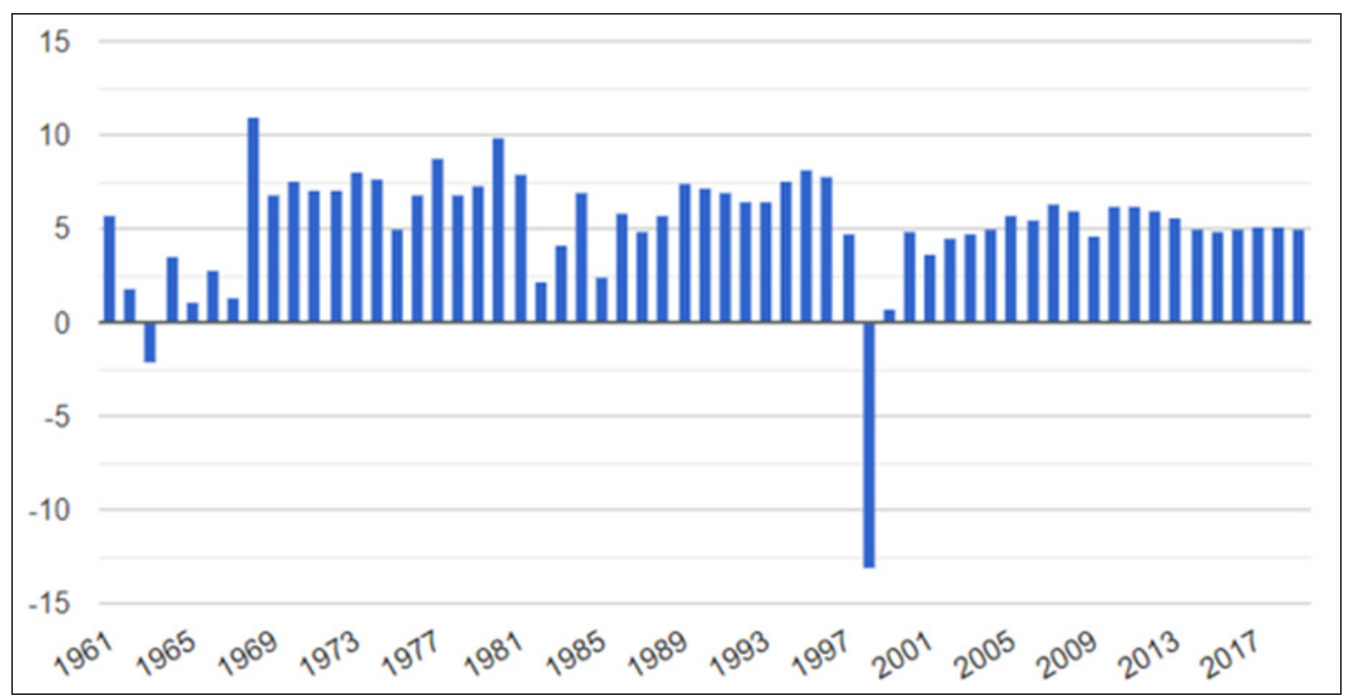

Source: The GE (2020)

This is supported by what we showed in Figure 1 economic growth from year to year (y-o-y) fluctuates. They recorded the highest GDP growth rate, reaching $10.92 \%$. Meanwhile, the lowest growth occurred in 1998, which reached $-13.13 \%$. The Indonesian economic recession occurred because of the economic crisis, especially from 1997 to 1998. In comparison, the average economic growth at the global level in 2019 was $2.77 \%$, so the average value of Indonesia's economic growth from 1961 to 2019 reached 5.60\% 
of 183 countries. This achievement explains that Indonesia's GDP growth is still on the world average, $2.60 \%$. Several factors, including demographic pressures, the happiness index, the human development index, and the labor force, caused Indonesia's GDP growth difficulties.

Most demographers and economists agree that essential elements for improving one's standard of living include the existence of the industry, urbanization, improving the quality of health and education, and increasing opportunities for employment in the non-agrarian sector. Thus, all these factors lead to changes and perceptions of the human being towards the cost of living, determining the whole (Sinding, 2009).

Jones (2011) also expressed the revolution against this view, who connected the concept of development and population growth. These two dimensions will always be a topic of concern and give a particular part in debates as time changes. Since the 1960s, the most dramatic changes have been economic growth and population explosion in historical civilizations. These two relationships are very relevant and always interesting to discuss. On the one hand, exploring predictions about the employment and share of individuals globally also raises many conflicts (Wijaya et al., 2021). The world has entered a digital era where humans are always racing to develop the technology. This did not occur, and statistics cannot prove this congruence. With the rapid presence of technology, it should help people's work.

However, expectations and reality are very contradictory, so it reduces the number of jobs and affects the transformation of the workforce. It has integrated the progress in the development of information technology with all economic sectors (Wiedmann et al., 2020). At least, there is a reduction in some employment in specific sectors through the intensity of the increasing demand for labor in other sectors, such as services, finance, administration, banking, and government (Stryzhak, 2020). This study tries to see the determination of happiness, demographic pressure, labor force, and human development on performing economic growth in Indonesia during the last five periods.

According to Raisová \& Ďurčová (2014), Malthus's model of per capita income is an essential part of measuring the welfare of the people of a country. Regarding economic growth, when per capita income exceeds the equilibrium level, we expect that productivity will increase and vice versa, the poverty rate suppressed. However, this model does not support case studies in some developing countries from the last ten decades.

Yiew \& Lau (2018) also shared the understanding of economic growth theory to discuss the congruent problem, which was pioneered by two stages in neoclassical theory. The explanation for the "Solow model" in the first stage is that even though population increases can affect exogenously stable economic growth. From the second stage, economic development in the economic growth model affects the birth rate, so productivity predominantly affects endogenous factors in the economic system (Karra et al., 2017).

Using the word "happy" is a term of evaluation in equating perception. Sometimes, from this understanding, the assumption about people having a happy life is almost 
the same as the perception that they have a prosperous life to fulfill their daily needs (physical and non-physical). In this way, the level of happiness is that people live well tautologically, meaning that it is only a measure of a decent life. Jency (2019) confirmed three basic views on measures of happiness, but only two have received significant attention in the philosophical literature. They defined happiness as "experience" as a whole and in part in life done with pleasure as an object to interpret it. Something closely related to family relations, so their treatment determines whether they are comfortable in the bond. Hedonism viewpoints can reduce the balance value in happiness because pleasure and displeasure are subject to nature (Conger et al., 2010).

There are currently demographic dynamics in developing countries because of population explosion and the availability of relatively adequate food. In facing the demographic bonus in the coming decades, the proportion of productive age population to the demand for work will increase (Hatton \& Williamson, 2003). For case studies in most countries that are members of the Organization for Economic Co-operation and Development (OECD), pensions in the public sector and health care are both very universal. It entitles only a tiny proportion of older adults entitled to protection against health care costs and social security (Bovenberg, 2008). These two factors imply a lower state fiscal burden in the future. There is a "ceteris paribus," which raises the potential to offer "growth dividends" from several countries to their residents.

The level of labor force participation, commonly known as the term "labor force," refers to individuals economically actively working in specific economic sectors (Doğan \& Akyüz, 2017). The number of workers includes those who have taken part in the labor market and do not work or take care of households but are looking for work. People who can work enter the labor force so that from the population that is not actively working. Polkowska (2019) and Pulignano (2019) state that those who do not work are not necessarily without income because this excludes people who work in the informal sector, wives who take care of the household, children, parents, people with disabilities, and residents of institutions.

Although the characterization in applied economic analysis takes place, in theory, the particular search for labor is precise to be discussed and plays a role in determining a policy. Seeking to review performance, the theoretical structure centers on labor market analysis. A particular population determines labor force participants in a country, so this illustrates that the resulting goods and services can reduce the frequency of unemployment (Doğan \& Akyüz, 2017).

Wijayanti \& Darma (2019), Nafukho et al. (2004), and Capuzzi et al. (2016) view that problems in human resource civilization have caused adverse effects because of development, so the concept of sustainable development is needed. By world experts, this requires a perspective to analyze and evaluate the current condition of human resources. When the productivity of human resources increases, it will make life on earth better.

Human development must be in line with an educated population which includes four interrelated concepts, i.e., People-Centered Development (PCD), Human 
Development, Human Resource Development (HRD), and Sustainable Development. The synergy of these four concepts can link the output to the Population-Oriented Development Index (PODI). In his measurement, Jalal (2014) uses five dimensions: sustainability, participation, equality, siding with the poor, and integration (see Figure 2).

Figure 2. Relationships in the concept of development

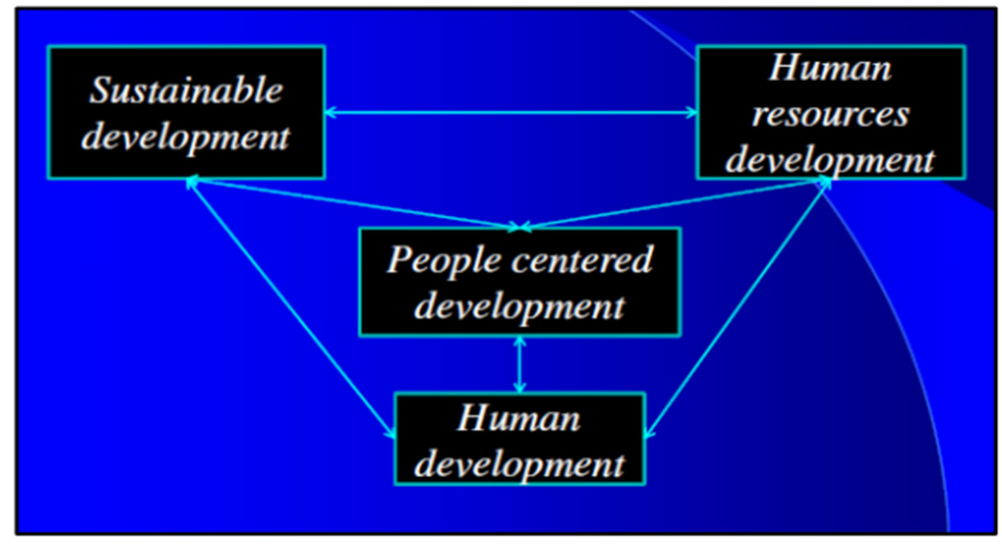

Source: Jalal (2014).

A theory is simply an explanation or interpretation of a set of phenomena. However, this has not been tested with certainty, but can be extensively, well supported, and accepted as an accurate description by the scientific community worldwide (Gänswein, 2011; UNDP, 2014; Dasic et al., 2020). In order to develop some hypotheses in this article, we need to present some opinions and confirm the previous empirical findings so that it can build the hypothesis.

This study is very appropriate to be reviewed and become the focus because it considers the novelty aspect. Empirical reviews and supporting theories have created a happiness gap in Indonesia because of the spatial impact caused by considerable demographic pressures. The effect that arises is the lack of a labor force that can trigger unemployment and increase poverty (Mubarak, 2020). Unproductive labor market competition also has a fatal impact on welfare, marked by an inadequate minimum wage. The consequences for improving $\mathrm{HD}$ are hampered, and the eventual results in socio-economic development will also be uneven.

\section{METHODS}

In this work, we collect data based on secondary data from The Global Economy report for Indonesia. Under the study objectives, the data referred to are happiness, demographic pressures, labor force, human development, and economic growth for five periods (2015-2019).

The objectivity of our study is decisive in Indonesia because this country very much depends on the primary sector (agriculture), but there is a degradation of human development and demographic pressures. With the quality of human development 
declining in parts of Eastern Europe because of reduced birth rates of those busy working and losing their "productive age," demographic pressure is widening. Productivity in human development declines, and high demographic pressure will affect the level of one's happiness, resulting in a decrease in productivity at work, leading to a recession in economic growth (Iosif, 2014; Duguleană, 2011).

The study approach is carried out quantitatively because it focuses on empirical models and the data summarized in time series for five periods. Some researchers consider the quantitative approach a "symbol of the scientific approach" because they explore it in depth through specific models or analysis tools (Quick \& Hall, 2015). Broadly, this study can summarize the effect of happiness, demographic pressures, labor force, and human development on economic growth in Indonesia.

To answer each of the hypotheses we have designed, the econometric method, in this case, is the Ordinary Least Square (OLS). This estimation method is most commonly used when applied to regular regression because it can display many desired properties. In addition, OLS is a statistical model to determine the relationship between certain variables. This analysis has broad coverage and is applied in most fields of science (Mahaboob et al., 2018). In a linear relationship between the dependent variable and the independent variable it can form a linear mathematical model with the following conditions:

$$
\mathrm{Y}_{\mathrm{i}}=\beta_{0}+\beta_{1} \mathrm{X}_{\mathrm{i}}+\varepsilon_{\mathrm{i}} \mathrm{i}=1,2, \ldots \ldots, \mathrm{n}
$$

Where: Y (dependent variable), $\beta$ (coefficients), $X$ (independent variable), $\varepsilon$ (error term), $\mathrm{i}$ (parameter), $\mathrm{n}$ (observations). The model to be used in operation is:

$$
\mathrm{EG}_{\mathrm{t}}=\alpha_{0}+\alpha_{1} \mathrm{H}_{\mathrm{t}}+\alpha_{2} \mathrm{DP}_{\mathrm{t}}+\alpha_{3} \mathrm{LF}_{\mathrm{t}}+\alpha_{4} \mathrm{HD}_{\mathrm{t}}+\varepsilon_{\mathrm{t}}
$$

Where: EG (economic growth), $\alpha$ (constant), H (happiness), DP (demographic pressures), LF (labor force), HD (human development), t (time series), and $\varepsilon$ (error term). To facilitate data analysis, we processed it with the Statistical Package for the Social Sciences (SPSS) software version 25. The program will present descriptive statistics, Person Correlation, correlation coefficient and coefficient of determination, and partial test stages.

\section{RESULTS AND DISCUSSION}

Kaur et al. (2018) inform that descriptive statistics summarize data in a measured manner by describing the relationship between variables in an observation. Researchers need to take this step before making inferential statistical comparisons because descriptive statistics are the first part. The overall variables in this study are the ratio (percentage) of fundamental indicators in achieving economic development in Indonesia with a measure of frequency.

The second step is the achievement of the Pearson correlation, where the value in the correlation is related to the relationship between the independent and dependent variables. According to Ratnasari et al. (2016), Pearson correlation is a type of correlation coefficient that explains the relationship between two variables as measured by the similarity of the 
ratio scale. In addition, this value also shows the strength of the relationship between two continuous variables.

Table 1. Value of descriptive statistics (obs. 25)

\begin{tabular}{lcc}
\hline \multicolumn{1}{c}{ Variables } & Mean & Std. deviation \\
\hline Economic growth & 4.8600 & 1.30681 \\
Happiness & 5.8980 & .23616 \\
Demographic pressures & 3.1600 & .42778 \\
Labor force & 54.5760 & .53854 \\
Human development & .8086 & .00623 \\
\hline
\end{tabular}

Source: Author's tabulation.

Given that the size of each variable is different, it cannot be uniform. The achievement in descriptive statistics determines the various mean values of the five variables. Table 1 explains that the highest mean for the labor force for five periods is 54.5760 and the lowest in human development, namely 0.8086. From other calculations, economic growth is precisely the variable with the highest standard deviation reaching 1.30681 .

There are three variables with negative values determining demographic pressures (happiness, labor force, and human development). Only one positive variable shapes demographic pressures, namely economic growth reaching 3.9\%. Meanwhile, the most dominant performance of the Pearson correlation is from economic growth with the variables that influence it, where the four variables, only human development, has the lowest correlation up to $-0.9 \%$ and the highest in shaping economic growth is the labor force amounted to $30.7 \%$.

Table 2. Value of Pearson correlation and sig. (1-tailed)

\begin{tabular}{llccccc}
\hline Component & \multicolumn{1}{c}{ Variables } & [1] & [2] & [3] & [4] & [5] \\
\hline Pearson correlation & Economic growth & 1.000 & .195 & .039 & .307 & -.009 \\
& Happiness & .195 & 1.000 & -.951 & .463 & .975 \\
& Demographic pressures & .039 & -.951 & 1.000 & -.463 & -.993 \\
& Labor force & .307 & .463 & -.463 & 1.000 & .429 \\
& Human development & -.009 & .975 & -.993 & .429 & 1.000 \\
Sig. (1-tailed) & Economic growth &. & .377 & .475 & .307 & .494 \\
& Happiness & .377 &. & .006 & .216 & .002 \\
& Demographic pressures & .475 & .006 &. & .216 & .000 \\
& Labor force & .307 & .216 & .216 &. & .235 \\
& Human development & .494 & .002 & .000 & .235 &. \\
\hline
\end{tabular}

Source: Author's tabulation. 
Table 2 also reflects the one-way probability that highlights the relationship between economic growth, happiness, demographic pressures, labor force, and human development. Here, it can see if there are no variables that are significantly consistent with their relationship to other variables. None of the variables significantly impact economic growth and the labor force. However, two variables each have a significant effect on happiness, demographic pressures, and human development. Please note that we use a probability level of $5 \%$ to measure a one-way relationship.

Figure 3. Scatter plot of the dependent variable

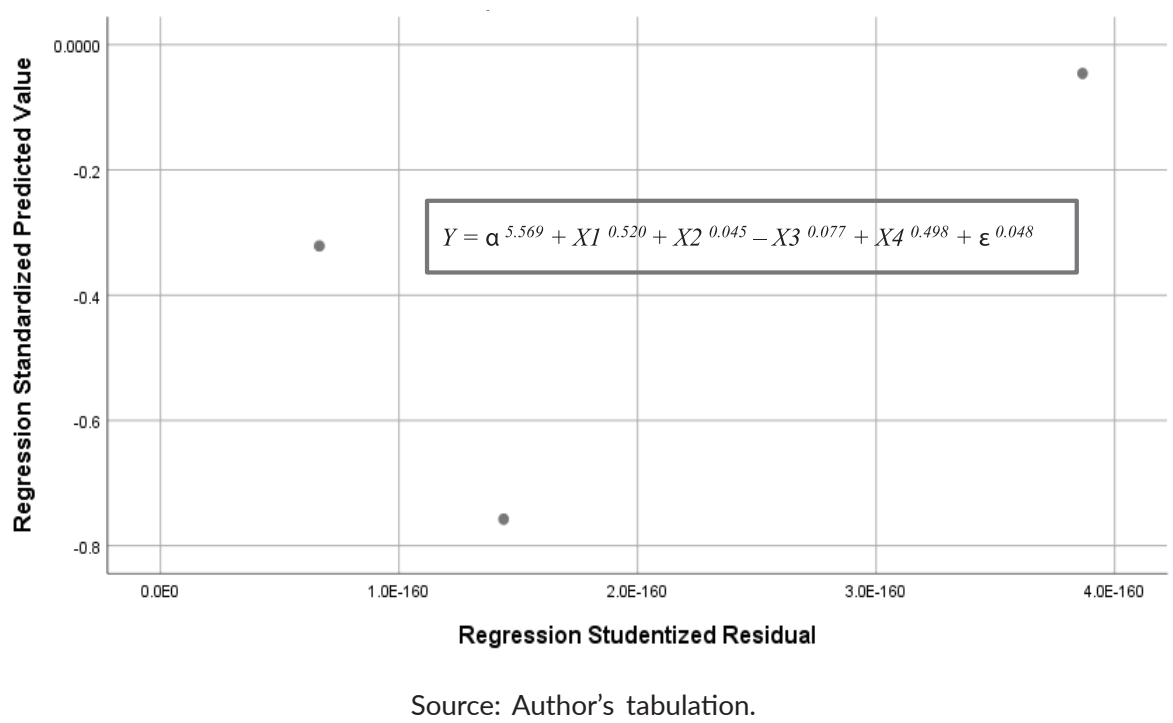

Figure 3 reports that a scatter diagram (distribution) shows the correlation between pairs of two kinds of variables and presents the closeness of the relationship between the two variables, which is often expressed as a correlation coefficient. The scatter plot function can also assess whether a variable replaces other variables (Ilmi et al., 2020). Here, there is a positive correlation, and it means that the combination of four variables (happiness, demographic pressures, labor force, and human development) can determine economic growth in Indonesia so that economic growth to be controlled.

Regression analysis is linear, so the dependent variable's increase must follow the proportional increase in the independent variable. It does not meet the linearity test, and it can carry data transformation out using quadratic, exponential, or other models that match the non-linear relationship pattern. We can use the correlation coefficient and determination in various statistical calculations. In OLS, the independent variable gives rise to the dependent variable.

The relationship between variables is linear, where changes constantly follow changes in the independent variable in the dependent variable - the coefficient of determination results from the square of the correlation coefficient. The calculation of the correlation coefficient and the coefficient of determination have a similar function, namely calculating the strength or absence of the relationship between two variables (Suparjo et al., 2021). 
Interpretation for the correlation coefficient, the relationship between variables between 0 (very weak) to 1 (very strong), while the measure in the coefficient of determination can also determine the value of the residual factor.

Table 3. Model summary

\begin{tabular}{ccccccc}
\hline Model & $\mathbf{R}$ & $\begin{array}{c}\mathbf{R} \\
\text { Square }\end{array}$ & $\begin{array}{c}\text { Adjusted } \mathbf{R} \\
\text { Square }\end{array}$ & $\begin{array}{c}\text { Std. error of the } \\
\text { Estimate }\end{array}$ & $\begin{array}{c}\text { R Square } \\
\text { Change }\end{array}$ & $\begin{array}{c}\text { Durbin- } \\
\text { Watson }\end{array}$ \\
\hline 1 & .976 & .952 & .939 & .15128 & .952 & 2.289 \\
\hline
\end{tabular}

Source: Author's tabulation.

Meanwhile, the regression structure proves that the correlation value (R) is $97.6 \%$, meaning that the variables' closeness is extreme because it is almost close to $100 \%$. The quadratic correlation $\left(\mathrm{R}^{2}\right)$ reached $95.2 \%$, illustrating the value of confounding factors of $4.8 \%$ outside the study model. Based on Table 3, the Durbin-Watson (DW) value describes a test used to detect the occurrence of autocorrelation on prediction errors from a regression analysis, so the condition is that there is negative autocorrelation or is free from autocorrelation problems.

We need to describe the alignment between the study hypothesis and partial testing at this stage. The absolute requirement is whether the hypothesis is accepted or rejected based on statistical criteria in OLS. Table 4 describes the extent of the influence of the independent variable on the dependent variable. Constantly, the involvement of happiness, demographic pressures, labor force, and human development to predict economic growth in Indonesia is positive. If divided based on the relationship of each variable, only the labor force has a negative and insignificant effect on economic growth. This means that an increase in the labor force of $1 \%$ will reduce economic growth by $7.7 \%$ in the long run. Other analysis results confirm the positive and significant relationship between happiness, demographic pressures, and human development on economic growth. The continuity of these three variables implies that it can still consistently determine the increase in economic growth in the future. The most dominant variable for the sustainability of economic growth is demographic pressures because the probability is the smallest compared to the others.

Table 4. Estimates of regression

\begin{tabular}{cccccccc}
\hline Hypothesis & Coeff. & SE & t-Statistic & Prob. & Tolerance & Accepted & Rank \\
\hline (Constant) & 1.389 & 1.750 & 1.023 & .030 & & & \\
H1 & .520 & .133 & 1.185 & .045 & .012 & Yes & 3 \\
H2 & .045 & .102 & .179 & .016 & .035 & Yes & 1 \\
H3 & -.077 & .081 & -.352 & .252 & .014 & No & 4 \\
H4 & .498 & .278 & 1.214 & .038 & .048 & Yes & 2 \\
\hline
\end{tabular}

Source: Author's tabulation, Note: Dependent variable (economic growth). 
Our results show that most of the hypotheses are acceptable $(\mathrm{H} 1, \mathrm{H} 2$, and $\mathrm{H} 4)$. For the rest, one hypothesis is rejected (H4). It should be noted that this article has answered the differences between some of the literature and previous studies. The major problem with the increase in economic growth is that there are increasingly actual differences between the poor and the rich, causing inequality in income from a country and even globally. Initially, when the leading economies (Adam Smith) first laid the foundations in economic theory, the income gap between the poor and the rich was narrower (Acemoglu \& Dell, 2010). After that, when the industrial revolution was present in developing countries to reduce poverty, disparities widened, and the experience of countries classified as advanced was the opposite. Initially, several countries in the Asian region, such as South Korea, Singapore, and Japan, which were classified as developing countries, could economically develop the level of welfare of their population compared to other countries. This is more similar to what developed countries do through export expansion through increasing production capacity for goods and services (Soyer et al., 2020; Stefan, 2012).

Since 2010, observers and economists have been researching happiness, providing empirical knowledge of the mechanisms of happiness, and creating a model that looks at the processes that make people happy. The public has accepted the work's success because it contributes substantially to describing one's happiness and well-being. With the emergence of positive psychology, there has also been an increase in interest from the positive side in paying attention to positive things because of human involvement in economic activities, organizational life, affective experiences in the world of work, and their satisfaction with work (Furnham \& Cheng, 2000; Haybron, 2003).

Explicitly, the demographic transition begins in the $21^{\text {st }}$ century and is alleged amidst remarkable differences. Infant mortality rates have dropped sharply, with adult life expectancy also increasing. Although the fertility rate declined significantly from the $20^{\text {th }}$ century in developed countries, it has penetrated developing countries. The existence of this demographic change in industrialized countries (such as China, the USA, and Japan) has sharp consequences in influencing the population's age structure, resulting in a reduction in the number of young (productive) people in adults. This transition has continued today. Developed countries will experience severe population decline in the coming decades. As a result, because most of the population postpone the "marriage period" and "desire to have children," the fertility rate will decrease, and the dependence of the elderly will increase significantly. This comparison ratio will also occur in developing countries (Lee, 2003; Bello-Ochende et al., 2010).

Variations will arise in the supply of labor in specific sectors. Case studies in many countries show that the supply of labor is closely related to the dynamics of the business cycle, which shows that the labor market is in a "perfect competition" point with the supply of labor that is tight so that the unemployment rate also increases drastically (Darma et al., 2020). The explanation for this phenomenon is prevalent because, during the economic recession, workers give up and become desperate to find work. Economists view these problems because of their meager chances of finding a job, so the psychological 
and monetary costs of finding utility are much lower when compared to the labor force consequences. The policy that can pursue is through workers' wages, which are determined based on rates or turnover in the business cycle.

The highlighting of the importance of absolute value over ranking in dealing with the dimensions and indicators of HDI has become a concern with this issue. This is because countries are competing to display HDI rankings compared to solving genuine problems such as quality of education, quality of health, and connectivity of income distribution so as not to experience a significant gap. For this reason, the government needs to make efforts to design and practice development priority programs (Panigrahi \& Sivramkrishna, 2002; Morse, 2003; Osberg \& Sharpe, 2003; Cherchye et al., 2004; Segura \& Moya, 2009).

Figure 4. Demographic pressures and labor market: young age v.s old age

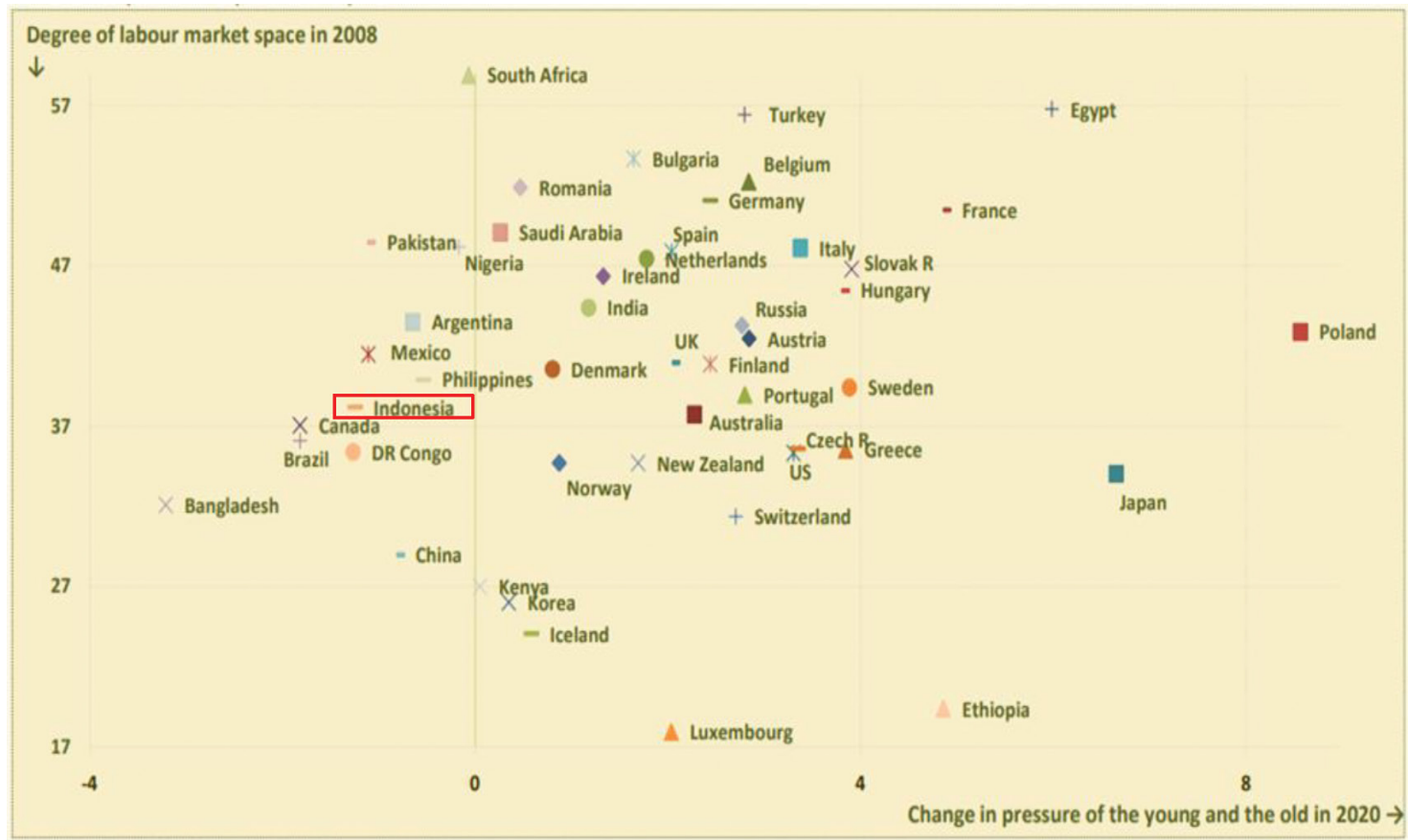

Source: Peeters \& Groot (2012), Note: Labor market (\%) and demographic pressures (\% of GDP)"*.

Studies of pure demographic pressures, labor force, and economic development have been reviewed in recent decades. We expect something new about the process to increase employment and economic growth. The period of transition from demographic pressures affects the population's lives (for example, the environment in which they live). The decline in fertility is the beginning of social development factors in specific periods (Fox et al., 2018). Many deaths have created new problems for labor productivity (Rizal \& Fitrianto, 2021).

Figure 4 highlights the dynamic perspective between demographic pressures and the labor space for the 2008-2020 period. Interestingly, it centered most countries in the middle of going through a slight increase in the combination of a relatively high 
variation in the labor space, although case studies in several countries appear to have seen a sizeable increase as for the average demographic pressure of total GDP from 2010 to 2020 at $8 \%$. However, the limited set is heterogeneous for several countries preparing to face a decline in fiscal spending. This phenomenon also describes changes in demographic pressures versus the labor market space. Thus, a summary of these figures provides graphical information on the ranking of countries. They measured their performance by indicators of demographic pressure that have a direct two-way relationship with economic growth. The lack of seriousness of poor and developing countries in determining direction through instruments that are less synergistic with the provision of employment can also lead to new problems such as reduced labor happiness and fatal consequences for not achieving sustainable human development.

The highlight of this study, with the empirical results conducted by previous researchers, is essential for comparison. First, the relationship between economic growth and levels of well-being as measured by happiness over time is like this study. Stevenson \& Wolfers (2008) and Clark et al. (2008) found that total income contributed to the level of happiness. Second, the results of studies by Nuță \& Nuță (2020) and Fent el. (2008) found that demographic factors contribute to economic growth in parts of Europe, which has been contradicting our study's outcome. Third, Altuzarra et al. (2019) and Herman (2011) found that increasing female labor force participation can improve conditions for economic growth in several EU countries. The existence of a "U" shaped relationship between economic development and the female workforce confirms that the study hypothesis is in line with this. Only economic growth will guarantee new jobs generate human development and conditions for inclusive economic growth. Fourth, this work displays the human development represented by HDI in positive synergy for economic growth. The results are also in line with the study by Leiwakabessy \& Amaluddin (2020), which reveals a strong two-way relationship between development and economic growth in Indonesia. As additional information, Ali \& Cantner (2020) found empirical evidence of a positive level of welfare capable of significant human development for 20 European countries in 1996-2010.

It is also no less interesting to see the happiness of a person. Residents who live in an area can feel comfortable and, it is a sign that they will create harmonious conditions. The family environment is not the only aspect that plays a vital role in the population, but social relations, culture, health, education, work, and household income ( $\mathrm{Li}, 2016)$. The presence of the government can accommodate these aspects to create security so that they can carry out activities as usual. We can imagine, in conflict-prone countries like Africa and the Middle East, it is very worrying for those who live there. This tense situation has a terrible impact on running the economy from the labor side and getting a decent life.

\section{CONCLUSION}

From the calculations using OLS analysis, we can conclude that happiness, demographic pressures, and human development have significantly affected Indonesian 
economic growth in the last five periods, while the labor force did not have a significant effect. To rank, demographic pressure is the primary variable that can determine the dominant economic growth, so demographic pressure comes first. The performance of human development and happiness only leads to the second and third ranks. Happiness and human development also play an essential role in increasing economic growth, even though the relationship is not that big compared to demographic pressures.

Reduced per capita income can become an additional problem for the social disparity. Inclusive economic growth is a space where they can carry out the economic process itself. Whether it is in terms of production, distribution, and sustainable consumption of the population, all of them become the benchmarks of every country. Some issues remain open regarding the essential questions in this article to encourage future research. Overall, we recognize that there is still a lack of conformity with the study objectives. With these limitations, we hope it can provide something more varied to develop according to the topic being studied.

Policy recommendations need to be implemented by the government, which has a role as regulator, allocator, stabilizer, and distributor to revitalize several technical policies related to social mobility, education, health, and market structure to provide suitable public needs.

\section{REFERENCES}

Acemoglu, D., \& Dell, M. (2010). Productivity Differences between and within countries. American Economic Journal: Macroeconomics, 2(1), 169-88. https://doi.org/10.1257/ mac.2.1.169.

Ali, M., \& Cantner, U. (2020). Economic diversification and human development in Europe. Eurasian Economic Review, 10, 211-235 (2020). https://doi.org/1007/ s40822-020-00147-0.

Altuzarra, A., Gálvez-Gálvez, C., \& González-Flores, A. (2019). Economic Development and Female Labour Force Participation: The Case of European Union Countries. Sustainability, 11(7), 1962; https://doi.org/10.3390/su11071962.

Anderson, T., \& Kohler, H. (2015). Low Fertility, Socioeconomic Development, and Gender Equity. Population and Development Review, 41(3), 381-407. https://doi. org/10.1111/j.1728-4457.2015.00065.x.

Bello-Ochende, T., Meyer, J. P., \& Ighalo, F. U. (2010). Combined Numerical Optimization and Constructal Theory for the Design of Microchannel Heat Sinks. Numerical Heat Transfer, Part A: Applications, 58(11), 882-899. https://doi.org/10.1080/104 07782.2010.529036.

Bovenberg, A. L. (2008). The Life-course Perspective and Social Policies: An Overview of the Issues. CESifo Economic Studies, 54(4), 593-641. https://doi.org/10.1093/ cesifo/ifn029.

Capuzzi, D., Stauffer, M. D., \& O'Neil, T. (2016). Theories of human development. 
In D. Capuzzi \& M. D. Stauffer (Eds.), Human growth and development across the lifespan: Applications for counselors (p. 25-53). Hoboken, NJ: John Wiley \& Sons, Inc. https://scholarworks.waldenu.edu/sc_pubs/130/.

Cherchye, L., Moesen, W., \& Van Puyenbroeck, T. (2004). Legitimately diverse, yet comparable: synthesizing social inclusion performance in the EU. Journal of Common Market Studies, 42(5), 919-955. https://doi.org/10.1111/j.00219886.2004.00535.x.

Clark, A. E., Frijters, O., \& Shields, M. (2008). Relative Income, Happiness, and Utility: An Explanation for the Easterlin Paradox and Other Puzzles. Journal of Economic Literature, 46(1), 95-144. https://doi.org/10.1257/jel.46.1.95.

Conger, R. D., Conger, K. J., \& Martin, M. J. (2010). Socioeconomic Status, Family Processes, and Individual Development. Journal of Marriage and the Family, 72(3), 685-704. https://doi.org/10.1111/j.1741-3737.2010.00725.x.

Darma, D. C., Kasuma, J., \& Ikbal, M. (2020). Employment Absorption: Elasticity in the Industry and Services Sector in Indonesia. Management and Economics Review, 5(1), 125-135. https://doi.org/10.24818/mer/2020.06-10.

Dasic, B., Devic, Z., Denic, N., Zlatkovic, D., Ilic, I. D., Cao, Y., Jermsittiparsert, K., \& Le, H. V. (2020). Human development index in a context of human development: Review on the western Balkans countries. Brain and Behavior, 10(9), 1-12. https:// doi.org/10.1002/brb3.1755.

Daud, N. (2017). The Effect of Sector Economic Growth on the Performance of Employment and Welfare of People. International Journal of Business and Management, 12(9), 194-203. https://doi.org/10.5539/ijbm.v12n9p194.

Demirbolat, A. O. (2018). Democracy, Human Development, and Happiness Indices as Precursors of International Student Success. Journal of Education and Learning, 7(1), 237-244. https://doi.org/10.5539/jel.v7n1p237.

Doğan, B., \& Akyüz, M. (2017). Female labor force participation rate and economic growth in the framework of Kuznets curve: Evidence from Turkey. Review of Economic and Business Studies, 10(1), 33-54. https://doi.org/10.1515/rebs-20170047.

Duguleană, C. (2011). Effects of the economic crisis in Romania. SEER: Journal for Labour and Social Affairs in Eastern Europe, 14(1), 17-25. https://www.jstor.org/ stable/43293397.

Fent T., Mahlberg B., \& Prskawetz A. (2008). Demographic Change and Economic Growth. In: Kohlbacher F., Herstatt C. (eds) The Silver Market Phenomenon. Heidelberg, Berlin: Springer. https://doi.org/10.1007/978-3-540-75331-51.

Fox, J., Klüsener, S., \& Myrskylä, M. (2018). Is a Positive Relationship Between Fertility and Economic Development Emerging at the Sub-National Regional Level? Theoretical Considerations and Evidence from Europe. European Journal of Population, 35(3), 487-518. https://doi.org/10.1007/s10680-018-9485-1. 
Furnham, A., \& Cheng, H. (2000). Lay Theories of Happiness. Journal of Happiness Studies, 1, 227-246. https://doi.org/10.1023/A:1010027611587.

Gänswein W. (2011) Theory and hypotheses development. In: Effectiveness of Information Use for Strategic Decision Making. Gabler. https://doi.org/ 10.1007/978-3-83496849-4_4.

Hatton, T. J., \& Williamson, J. G. (2003). Demographic and Economic Pressure on Emigration out of Africa. The Scandinavian Journal of Economics, 105(3), 465-486. https://doi.org/10.1111/1467-9442.t01-2-00008.

Haybron, D. M. (2003). What do we Want from a Theory of Happiness?. Metaphilosophy, 34(3), 305-329. https://doi.org/10.1111/1467-9973.00275.

Herman, E. (2011). The Impact of Economic Growth Process on Employment in European Union Countries. Romanian Economic Journal, 14(42), 47-67.

Ilmi, Z., Darma, D. C., \& Wijayanti, T. C. (2020). Can servqual mediate from the store atmosphere and customer satisfaction?. Management Theory and Studies for Rural Business and Infrastructure Development, 42(3), 359-368. https://doi.org/10.15544/ mts.2020.36.

Iosif, M. (2014). The Limits" of Economic Growth in Romania. Procedia Economics and Finance, 16, 308 - 313. https://doi.org/10.1016/S2212-5671(14)00807-7.

Jalal, F. (2014). Pembangunan Berwawasan Kependudukan. Seminar Nasional Kependudukan. Bandung: BKKBN Republik Indonesia. https://cpps.ugm.ac.id/pembangunan-harusberwawasan-kependudukan/.

Jency, M. (2019). "Happiness Index"- The Footsteps towards Sustainable Development. International Research Journal of Engineering and Technology, 6(12), 615-619.

Jones, G. W. (2011). Population and development beyond the first demographic transition: a focus on the experience of east and southeast Asian countries. Revista Brasileira de Estudos de População, 28(2), 267-281. https://doi.org/10.1590/S010230982011000200002.

Karra, M., Canning, D., \& Wilde, J. (2017). The Effect of Fertility Decline on Economic Growth in Africa: A Macrosimulation Model. Population and Development Review, 43(1), 237-263. https://doi.org/10.1111/padr.12009.

Kaur, P., Stoltzfus, J., \& Yellapu, V. (2018). Descriptive statistics. International Journal of Academic Medicine, 4(1), 60-63. https://doi.org/10.4103/IJAM.IJAM_7_18.

Lee, R. D. (2003). The Demographic Transition: Three Centuries of Fundamental Change. Journal of Economic Perspectives, 17(4), 167-190. https://doi.org/10.1257/ 089533003772034943.

Leiwakabessy, E., \& Amaluddin, A. (2020). A modified human development index, democracy, and economic growth in Indonesia. Humanities \& Social Sciences Reviews, 8(2), 732-743. https://doi.org/10.18510/hssr.2020.8282.

Li, Y. (2016). The Relationship between Fertility Rate and Economic Growth in Developing Countries. Master thesis. 
Mahaboob, B., Venkateswarlu, B., Narayana, C., Sankar, J. R., \& Balasiddamuni, P. (2018). A Treatise on Ordinary Least Squares Estimation of Parameters of Linear Model. International Journal of Engineering \& Technology, 7(4.10), 518-522. https:// doi.org/10.14419/ijet.v7i4.10.21216.

Mubarak, M. S. (2020). The Impact of Population, Labor, Unemployment, and Poverty on Economic Growth Regencies/Municipality in Sulawesi Tengah Province. Jurnal Ekonomi Pembangunan, 18(1), 62-79. https://doi.org/10.22219/jep.v18i1.11736.

Morse, S. (2003). Greening the United Nations' Human Development Index?. Sustainable Development, 11(4), 183-198. https://doi.org/10.1002/sd.219.

Nafukho, F. M., Hairston, N., \& Brooks, K. (2004). Human capital theory: Implications for human resource development. Human Resource Development International, 7(4), 545-551. https://doi.org/10.1080/1367886042000299843.

Nuţă, A-C., \& Nuţă, F-M. (2008). Modeling the Influences of Economic, Demographic, and Institutional Factors on Fiscal Pressure Using OLS, PCSE, and FD-GMM Approaches. Sustainability, 12, 1681. https://doi.org/10.3390/su12041681.

Osberg, L., \& Sharpe, A. (2003). Human Well-being and Economic Well-being: What Values Are Implicit in Current Indices?. Centre for the Study of Living Standards Research Report 2003/04. Ottowa: Centre for the Study of Living Standards.

Panigrahi, R., \& Sivramkrishna, S. (2002). An Adjusted Human Development Index: Robust Country Rankings concerning the Choice of Fixed Maximum and Minimum Indicator Values. Journal of Human Development, 3(2), 301-311. https://doi.org/ 10.1080/14649880220147365.

Peeters, M., \& Groot, L. F. (2012). A Global View on Demographic Pressure and Labour Market Participation. Journal of Global Economy, 8(2), 165-194. https:// doi.org/10.2139/ssrn.1881359.

Polkowska, D. (2019). Does the App Contribute to the Precarization of Work? The Case of Uber Drivers in Poland. Partecipazione e Conflitto, 12(3), 717-741. https://doi. org/10.1285/i20356609v12i3p717.

Pulignano, V. (2019). Work and Employment under the Gig Economy. Partecipazione e Conflitto, 12(3), 629-639. https://doi.org/10.1285/i20356609v12i3p629.

Quick, J., \& Hall, S. (2015). Part Three: The Quantitative Approach. Journal of Perioperative Practice, 25(10), 192-196. https://doi.org/10.1177/175045891502501002.

Raisová, M., \& Ďurčová, J. (2014). Economic Growth-supply and Demand Perspective. Procedia Economics and Finance, 15, 184-191. https://doi.org/10.1016/S22125671(14)00476-6.

Ratnasari, D., Nazir, F., Toresano, L., Pawiro, S. A., \& Soejoko, D. S. (2016). The correlation between adequate renal plasma flow (ERPF) and glomerular filtration

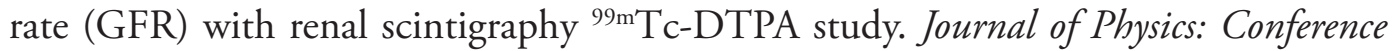
Series, 694, 012062. https://doi.org/10.1088/1742-6596/694/1/012062. 
Rizal, S., \& Fitrianto, A. (2021). Can revenue and human development promote happiness (Study on Provinces in Indonesia). Signifikan: Jurnal Ilmu Ekonomi, 10(1), 113 - 128. https://doi.org/10.15408/sjie.v10i1.17600.

Segura, S. L., \& Moya, E. G. (2009). Human Development Index: A non-compensary assessment. Cuadernos de Economía, 28(50), 222-235.

Sinding S. W. (2009). Population, poverty, and economic development. Philosophical transactions of the Royal Society of London. Biological Sciences, 364(1532), 30233030. https://doi.org/10.1098/rstb.2009.0145.

Stefan, G. (2012). Considerations on the Theory of Economic Growth and Development. Procedia - Social and Behavioral Sciences, 62, 280-284. https://doi.org/10.1016/j. sbspro.2012.09.045.

Stevenson, B., \& Wolfers, J. (2008). Economic Growth and Subjective Well-Being: Reassessing the Easterlin Paradox. Brookings Papers on Economic Activity, Spring 2008 (pp. 1-87). https://doi.org/10.1353/eca.0.0001.

Stryzhak, O. (2020). The relationship between education, income, economic freedom, and happiness. SHS Web of Conferences, 75, 03004. https://doi.org/10.1051/ shsconf/20207503004.

Soyer, K., Ozgit, H., \& Rjoub, H. (2020). Applying an Evolutionary Growth Theory for Sustainable Economic Development: The Effect of International Students as Tourists. Sustainability, 12(1), 418. https://doi.org/10.3390/su12010418.

Suparjo, S., Darma, S., Kurniadin, N., Kasuma, J., Priyagus, P., Darma, D. C., \& Haryadi, H. (2021). Indonesia's new SDGs agenda for green growth - emphasis in the energy sector. International Journal of Energy Economics and Policy, 11(3), 395-402. https://doi.org/10.32479/ijeep.11091.

The Global Economy. (2020). Indonesia: Economic growth. https:/www.theglobaleconomy. $\mathrm{com} /$ Indonesia/Economic_growth/.

The United Nations Development Programme. (2014). Human development report 2014, sustaining human progress: Reducing vulnerabilities and building resilience. New York: UNDP. http://hdr.undp.org/sites/default/files/hdr14-report-en-1.pdf.

Wijaya, A., Kasuma, J., Tasenţe, T., \& Darma, D. C. (2021). Labor force and economic growth based on demographic pressures, happiness, and human development: Empirical from Romania. Journal of Eastern European and Central Asian Research, 8(1), 40-50. https://doi.org/10.15549/jeecar.v8i1.571.

Wijayanti, T. C., \& Darma, D. C. (2019). The Role of Investment and Government Expenditure on GRDP and Human Development in East Kalimantan. International Journal of Scientific \& Technology Research, 8(9), 1232-1237.

Wiedmann, T., Lenzen, M., Keyßer, L. T., \& Steinberger, J. K. (2020). Scientists' warning on affluence. Nature Communications, 11(1), 3107. https://doi.org/10.1038/s41467020-16941-y. 
Yiew, T. H., \& Lau, E. (2018). Does foreign aid contributes to or impede economic growth. Journal of International Studies, 11(3), 21-30. https://doi.org/10.14254/20718330.2018/11-3/2.

Zainurossalamia, S., Amalia, S., Darma, D. C., \& Azis, M. (2021). Spurring Economic Growth in Terms of Happiness, Human Development, Competitiveness, and Global Innovation: the ASEAN Case. ASEAN Journal on Science and Technology for Development, 38(1), 1-6. https://doi.org/10.29037/ajstd.653. 